\title{
Cold room thermoregulation, store consumption, and survival of Africanized and European honey bees (Apis mellifera $L$ )
}

\author{
JD Villa, TE Rinderer \\ USDA, ARS Honey-Bee Breeding, Genetics and Physiology Research, 1157 Ben Hur Rd, \\ Baton Rouge, LA 70820-5502, USA
}

(Received 14 September 1992; accepted 6 April 1993)

\begin{abstract}
Summary - The potential of Africanized honey bees to survive winters was evaluated by comparing them in groups ( $40 \mathrm{~g}, 1.0 \mathrm{~kg}, 1.5 \mathrm{~kg}$ or whole colonies) to European bees in cold rooms. Africanized workers caged in $40-\mathrm{g}$ groups at $15^{\circ} \mathrm{C}$ aggregated in different positions and in tighter conformations, removed significantly lower amounts of sucrose syrup from feeders, and had higher mortalities than European workers. Africanized bees in 1.0-kg groups also had lower rates of syrup removal but were similar to European groups in aggregation and core temperatures. Groups of 1.5 $\mathrm{kg}$ showed similar temperature profiles inside the hives. Whole colonies of both types exposed to temperatures $\approx 0^{\circ} \mathrm{C}$ died before $10 \mathrm{wk}$, and did not differ significantly in amounts of recovered dead workers, or in weight loss. These results suggest that some of the important behavioral components of overwintering are present in Africanized honey bees.
\end{abstract}

\section{Africanized honey bee / cold tolerance / survival / thermoregulation}

\section{INTRODUCTION}

Africanized and European honey bees have been categorized respectively as 'tropically and temperately adapted' organisms based upon their native ranges and life history characteristics (Winston et al, 1984; Danka et al, 1987). Differences in the ranges of these 2 bee types as feral populations after their human-assisted introduction to the Americas have also been explained as a consequence of these contrasting evolutionary strategies (Taylor,
1977, 1985; Taylor and Spivak, 1984; Winston et al, 1984). European bees have been present in temperate areas af North America for several centuries (Kritsky, 1991). Tropical areas of South America did not appear to have sizable Europeanderived feral populations, but since 1956 these areas have been rapidly occupied by African-derived honey bees (Taylor, 1977). The adaptation paradigm has been further substantiated by the much slower movement of African-derived honey bees into subtropical areas of Brazil and Argen- 
tina and by the presence of largely European bees in temperate Argentina (Kerr et al, 1982; Sheppard et al, 1991).

Given this clear difference in density and distribution it is not surprising that several hypotheses have been presented to explain possible differential survival under cold or winter conditions: 1) Africanized bees may be less precise at maintaining thermal homeostasis through imperfect heat generation and aggregation (Nuñez, 1979); 2) smaller worker size and less precise aggregation might produce higher mass specific metabolic rates at cold temperatures and lead to the early depletion of already small winter stores (Taylor, 1977; Southwick et al, 1990); or 3) 'tropical' life history traits such as shorter worker lifespan and continued brood production during winter months might lead to colony winter mortality (Taylor and Spivak, 1984). We conducted 4 experiments with groups of different sizes to quantify these possible differences in thermoregulation, aggregation, store consumption and worker and colony longevity.

\section{MATERIALS AND METHODS}

Experiments were conducted in a cold room in Acarigua, Venezuela during 1986 and 1987. Bees of 3 different stock types were used: European bees from mated queens imported from the US (E), Africanized bees from local queens with a feral origin (A), or European daughter queens that had mated with feral drones and therefore produced largely $F_{1}$ hybrid workers $(E$ $x$ A). Four different experiments were designed to compare behavioral and physiological components of overwintering among the types.

\section{Experiment 1: forty $g$ of workers in hoarding cages}

Brood from 64 colonies ( $33 \mathrm{E}, 31 \mathrm{~A}$ ) was allowed to emerge in incubators at $35^{\circ} \mathrm{C}$. A total of $75 \mathrm{E}$ and $77 \mathrm{~A}$ hoarding cages (Kulincevic and Rothenbuher, 1973) were filled with $40 \mathrm{~g}$ of adult workers from single colonies (mean number of workers \pm SE: $E=371 \pm 3.2, A=429 \pm$ 3.9). Caged workers (without queens) were provided with sugar syrup and water, and were maintained at ambient temperature $\left(22-30^{\circ} \mathrm{C}\right)$ for up to $3 \mathrm{~d}$ until all cages had been filled. Copper-constantan thermocouples were placed between the food vials in 55 of the cages.

At the beginning of the experiment all cages were given 2 vials with $50 \%$ sucrose and the cold room temperature was decreased to $15^{\circ} \mathrm{C}$ $\left( \pm 2.5^{\circ} \mathrm{C}\right)$. The cooling unit inside the room was controlled by a thermostat set at $15^{\circ} \mathrm{C}$ producing an intermittent air current that reached all the cages. This caused a cooling potential beyond that of still air at that temperature. For the first $11 \mathrm{~d}$, dead bees at the bottom of each cage were counted and removed. Also the positions of the clustered bees in each cage were recorded. An observer (blind to the identity of cages) classified them into 1 of 3 position categories: 1) 'non-viable' when separated from food vials; 2) roof when symmetrically hanging from the 'roof'; or 3) 'side' when on the roof and side wall but still in contact with feeders. Additionally, cluster tightness was scored in 1 of 6 cluster tightness categories ranging from no grouping and highly mobile bees (0), to very tightly packed and immobile bees (5). Syrup vials were weighed and replaced according to need on $d 2,4,6,8$ and 10.

Preliminary trials had indicated a tendency for Africanized workers to cluster away from feeders and die if contact with feeders was not re-established. Therefore, the cold room was opened for $2 \mathrm{~h}$ after daily observations so that the change to ambient temperatures $\left(>25^{\circ} \mathrm{C}\right)$ would allow workers to move, feed and relocate if necessary. Then the room was cooled again to $15^{\circ} \mathrm{C}\left( \pm 2.5^{\circ} \mathrm{C}\right)$ for the next $22 \mathrm{~h}$. Since many Africanized groups clustered in positions away from the thermocouples, the thermocouples in the first 55 cages were moved to cages with clusters near the feeder on $d 7$, and only temperatures obtained from within the cluster were used to compare differences among types.

Daily frequencies of cluster positions for each type were analyzed by G-tests (Sokal and Rohlf, 1981). Cluster tightness rankings were reduced to 3 classes $(0,1,2,3$, and 4,5$)$ to have sufficient numbers in each cell for analysis by type and day with $G$-tests. Temperatures inside the 
clusters on $d 7$ were compared by ANOVA. The rate of sugar syrup consumption per $g$ of live bees for each 2-d period was calculated and the values were compared by repeated measures ANOVA (Steel and Torrie, 1980; SAS Institute 1990).

\section{Experiment 2: one $\mathrm{kg}$ of workers in screen cages}

Workers $(1.0 \mathrm{~kg})$ were taken from each of $5 \mathrm{~A}$, $5 \mathrm{E}$ and $5 \mathrm{E} \times \mathrm{A}$ colonies and put into wooden cages with screened sides $(15 \times 25 \times 35 \mathrm{~cm})$. Cages were given a weighed feeder can with $50 \%$ sucrose solution over a screened hole (diameter $10 \mathrm{~cm}$ ) at the top of the cage. The cages were then maintained in the cold for 24-h intervals sequentially at $20,10,5$, and $0^{\circ} \mathrm{C}\left( \pm 2.5^{\circ} \mathrm{C}\right)$. At each temperature setting, the cross-sectional dimensions of the hanging cluster (maximun length and height as observed from the screened side) were measured at 20:00 $\mathrm{h}$ and at 8:00 $\mathrm{h}$ the following day. Also, cluster core temperatures were recorded with copperconstantan thermocouples connected to a telethermometer.

The rapid changes in temperatures in this first test caused leakage of syrup so that food consumption rates could not be estimated. Consequently, a second set of $10 \mathrm{~A}$ and $10 \mathrm{E} 1.0 \mathrm{~kg}$ screened groups were maintained at between 10 and $15^{\circ} \mathrm{C}$ for a period of $5 \mathrm{~d}$ and syrup comsumption was measured in these groups.

Maximum cross-sectional areas, ratios of length to height, and core temperatures of the clusters in the first test were compared by repeated measure ANOVA. Total consumption of sucrose syrup by the two types in the second test was compared by ANOVA.

\section{Experiment 3: colonies without brood}

Ten honey combs were placed into each of 4 empty screened hives. Copper constantan thermocouples were distributed in 7 -cm grids arranged inside each of the colonies as follows: 3 rows and 6 columns in the space between combs 5 and 6 (center); 2 rows and 4 columns in the spaces between combs 2 and 3 (left), and between combs 8 and 9 (right) (see figure 2 for the exact positions of thermocouples). Workers $(1.5 \mathrm{~kg})$ with a queen were added to each of the hives ( $2 \mathrm{~A}, 2 \mathrm{E})$. Temperatures at the thermocouple locations were recorded at 7:00 and 19:00 h over a 3-d period while ambient temperature oscillated between 10 and $15^{\circ} \mathrm{C}$; ambient temperatures were gradually decreased for $5 \mathrm{~d}$ until they oscillated between -2 and $+2^{\circ} \mathrm{C}$; a series of measurements were then made at the same times for $3 d$ at these new temperatures. Isotherms for $15,20,25$, and $30^{\circ} \mathrm{C}$ were drawn for each of the sections between combs (center, left and right) by interpolating the location of these temperatures between adjacent thermocouples.

\section{Experiment 4: colonies with brood}

Five $A$ and five $E$ colonies were selected as matched pairs from research apiaries. Comb weight and brood area were measured in the field. Colonies were then screened, transported, reweighed, and placed in a cold room at $15^{\circ} \mathrm{C}$. Adult worker biomass was estimated as the difference between total colony weight and the weight of combs plus hive. Temperatures were decreased over a period of $10 \mathrm{~d}$ to $0^{\circ} \mathrm{C}$, except for a period of $5 \mathrm{~d}$ where they rose to ambient due to failure of the cooling unit's compressor. Colonies remained in this cold room for $73 \mathrm{~d}$.

At the end of the experiment, combs and dead adults were weighed, and brood areas were remeasured. Total adult mortality, final brood area, and rate of weight loss $(\mathrm{kg}$ weight loss $/ \mathrm{kg}$ adults) were compared by ANOVA.

\section{RESULTS}

\section{Experiment 1}

There was a distinct difference between the types in the distribution of cluster position and cluster tightness of the $40-\mathrm{g}$ groups exposed to cooling by air currents at $15^{\circ} \mathrm{C}$ (tables I, II). These differences were fairly consistent through days as 
Table I. Number of cages with workers clustered in different positions of the cage, arranged by day and type (Experiment 1).

\begin{tabular}{|c|c|c|c|c|c|c|}
\hline \multirow[t]{2}{*}{ Day } & \multirow[t]{2}{*}{ Type } & \multicolumn{3}{|c|}{ Positions } & \multirow[t]{2}{*}{ G } & \multirow[t]{2}{*}{$P>G$} \\
\hline & & Non-viable & Roof & Side & & \\
\hline 2 & $\begin{array}{l}A \\
E\end{array}$ & $\begin{array}{r}33 \\
8\end{array}$ & $\begin{array}{r}7 \\
40\end{array}$ & $\begin{array}{l}37 \\
27\end{array}$ & 43.51 & $<0.005$ \\
\hline 3 & $\begin{array}{l}A \\
E\end{array}$ & $\begin{array}{r}26 \\
7\end{array}$ & $\begin{array}{l}11 \\
26\end{array}$ & $\begin{array}{l}40 \\
42\end{array}$ & 17.94 & $<0.005$ \\
\hline 4 & $\begin{array}{l}A \\
E\end{array}$ & $\begin{array}{c}20 \\
7\end{array}$ & $\begin{array}{l}14 \\
12\end{array}$ & $\begin{array}{l}43 \\
56\end{array}$ & 8.37 & $<0.025$ \\
\hline 5 & $\begin{array}{l}A \\
E\end{array}$ & $\begin{array}{r}15 \\
5\end{array}$ & $\begin{array}{l}22 \\
25\end{array}$ & $\begin{array}{l}40 \\
45\end{array}$ & 5.70 & $>0.100$ \\
\hline 6 & $\begin{array}{l}A \\
E\end{array}$ & $\begin{array}{r}18 \\
5\end{array}$ & $\begin{array}{l}28 \\
26\end{array}$ & $\begin{array}{l}31 \\
44\end{array}$ & 10.12 & $<0.010$ \\
\hline 7 & $\begin{array}{l}A \\
E\end{array}$ & $\begin{array}{r}22 \\
6\end{array}$ & $\begin{array}{l}21 \\
24\end{array}$ & $\begin{array}{l}34 \\
45\end{array}$ & 11.45 & $<0.005$ \\
\hline 8 & $\begin{array}{l}A \\
E\end{array}$ & $\begin{array}{r}20 \\
5\end{array}$ & $\begin{array}{l}22 \\
27\end{array}$ & $\begin{array}{l}35 \\
43\end{array}$ & 10.95 & $<0.005$ \\
\hline 9 & $\begin{array}{l}A \\
E\end{array}$ & $\begin{array}{l}24 \\
14\end{array}$ & $\begin{array}{l}24 \\
42\end{array}$ & $\begin{array}{l}29 \\
19\end{array}$ & 9.69 & $<0.010$ \\
\hline 10 & $\begin{array}{l}A \\
E\end{array}$ & $\begin{array}{l}20 \\
13\end{array}$ & $\begin{array}{l}17 \\
14\end{array}$ & $\begin{array}{l}40 \\
48\end{array}$ & 2.49 & $>0.100$ \\
\hline Total & $\begin{array}{l}A \\
E\end{array}$ & $\begin{array}{r}198 \\
70\end{array}$ & $\begin{array}{l}166 \\
236\end{array}$ & $\begin{array}{l}329 \\
369\end{array}$ & 78.01 & $<0.001$ \\
\hline
\end{tabular}

indicated by significant $G$-values for most days. When core temperatures were measured in groups that maintained contact with feeders, no differences were found between $A$ groups (mean = 21.55, $\mathrm{SE}=6.08, n=20$ ) and $\mathrm{E}$ groups (mean $=$ 22.96, $\mathrm{SE}=5.38, n=35)(F=0.03, \mathrm{df}=1$, 53; $P=0.8685)$. Africanized groups removed less sugar syrup per 2-d period during this experiment (table III). When the amount of syrup consumed was rated to the weight of live bees in each cage, Africanized workers removed less syrup per weight of bees during the first 3 measurement periods (table III); in the fourth 2-d period, when groups were the smallest due to mortality, the Africanized workers had a higher ratio of syrup removal. There was a steeper mortality curve (fig 1) for A workers even though the bees were allowed to recover daily by opening the cold room to ambient temperatures. 
Table II. Number of cages with workers clustered at different tightness, arranged by day and genotype (Experiment 1).

\begin{tabular}{|c|c|c|c|c|c|c|}
\hline \multirow[t]{2}{*}{ Day } & \multirow[t]{2}{*}{ Type } & \multicolumn{3}{|c|}{ Tightness } & \multirow[t]{2}{*}{ G } & \multirow[t]{2}{*}{$P>G$} \\
\hline & & $0-1-2$ & 3 & $4-5$ & & \\
\hline 2 & $\begin{array}{l}A \\
E\end{array}$ & $\begin{array}{r}2 \\
30\end{array}$ & $\begin{array}{l}42 \\
37\end{array}$ & $\begin{array}{r}33 \\
8\end{array}$ & 46.07 & $<0.001$ \\
\hline 3 & $\begin{array}{l}A \\
E\end{array}$ & $\begin{array}{r}5 \\
28\end{array}$ & $\begin{array}{l}43 \\
44\end{array}$ & $\begin{array}{r}29 \\
3\end{array}$ & 51.15 & $<0.001$ \\
\hline 4 & $\begin{array}{l}A \\
E\end{array}$ & $\begin{array}{r}9 \\
22\end{array}$ & $\begin{array}{l}32 \\
51\end{array}$ & $\begin{array}{r}35 \\
2\end{array}$ & 45.72 & $<0.001$ \\
\hline 5 & $\begin{array}{l}A \\
E\end{array}$ & $\begin{array}{r}6 \\
28\end{array}$ & $\begin{array}{l}36 \\
43\end{array}$ & $\begin{array}{r}35 \\
4\end{array}$ & 44.31 & $<0.001$ \\
\hline 6 & $\begin{array}{l}A \\
E\end{array}$ & $\begin{array}{r}2 \\
18\end{array}$ & $\begin{array}{l}40 \\
52\end{array}$ & $\begin{array}{r}32 \\
5\end{array}$ & 38.26 & $<0.001$ \\
\hline 7 & $\begin{array}{l}A \\
E\end{array}$ & $\begin{array}{r}5 \\
19\end{array}$ & $\begin{array}{l}25 \\
53\end{array}$ & $\begin{array}{r}41 \\
3\end{array}$ & 57.98 & $<0.001$ \\
\hline 8 & $\begin{array}{l}A \\
E\end{array}$ & $\begin{array}{l}12 \\
21\end{array}$ & $\begin{array}{l}32 \\
48\end{array}$ & $\begin{array}{r}27 \\
6\end{array}$ & 20.04 & $<0.001$ \\
\hline 9 & $\begin{array}{l}A \\
E\end{array}$ & $\begin{array}{l}19 \\
67\end{array}$ & $\begin{array}{r}34 \\
4\end{array}$ & $\begin{array}{r}17 \\
0\end{array}$ & 79.07 & $<0.001$ \\
\hline 10 & $\begin{array}{l}A \\
E\end{array}$ & $\begin{array}{l}14 \\
22\end{array}$ & $\begin{array}{l}22 \\
37\end{array}$ & $\begin{array}{r}23 \\
8\end{array}$ & 12.72 & $<0.001$ \\
\hline Total & $\begin{array}{l}A \\
E\end{array}$ & $\begin{array}{r}74 \\
255\end{array}$ & $\begin{array}{l}306 \\
369\end{array}$ & $\begin{array}{r}272 \\
39\end{array}$ & 307.48 & $<0.001$ \\
\hline
\end{tabular}

\section{Experiment 2}

Cluster measurements did not differ as much among bee types in larger $1.0-\mathrm{kg}$ groups in screened cages (table IV). In this case, the mean cross-sectional area and ratio of length to height did not differ significantly. These 2 attributes of clustering were strongly influenced by decreasing temperature in both types. However, a significant interaction between area and ambient tem- perature was caused by a greater change in cluster dimensions at the highest and lowest ambient temperature in the $E$ groups. Despite these differences in clustering, core temperatures were similar at each of the ambient temperatures and times of day (table $\mathrm{V}$ ). Even though aggregation and temperatures were similar in these $1.0-\mathrm{kg}$ groups, dramatically lower amounts of syrup were removed by $A$ bees maintained between 10 and $15^{\circ} \mathrm{C}$ (table IIIc). 
Table III. Sugar syrup ( $\mathrm{g}$ of $50 \%$ solution) removed by groups of bees of 2 genotypes at cold temperatures.

\begin{tabular}{|c|c|c|c|c|c|}
\hline & \multicolumn{2}{|c|}{ Type } & \multirow[t]{2}{*}{ Source } & \multirow[t]{2}{*}{$\mathrm{F}$} & \multirow[t]{2}{*}{$P>F$} \\
\hline & $E$ & $A$ & & & \\
\hline \multicolumn{6}{|l|}{ Experiment 1} \\
\hline a) Period 1 & $46.5 \pm 0.86$ & $33.1 \pm 1.29$ & Type & 228 & $<0.0001$ \\
\hline Period 2 & $36.5 \pm 1.38$ & $13.6 \pm 0.62$ & Time & 791 & $<0.0001$ \\
\hline Period 3 & $21.7 \pm 1.32$ & $4.7 \pm 0.26$ & Type-Time & 50 & $<0.0001$ \\
\hline Period 4 & $8.1 \pm 0.54$ & $3.2 \pm 0.32$ & & & \\
\hline b) Period 1 & $1.31 \pm 0.026$ & $0.92 \pm 0.36$ & Type & 20 & $<0.0001$ \\
\hline Period 2 & $1.08 \pm 0.028$ & $0.46 \pm 0.020$ & Time & 23 & $<0.0001$ \\
\hline Period 3 & $0.71 \pm 0.029$ & $0.26 \pm 0.010$ & Type-Time & 8 & $<0.0001$ \\
\hline Period 4 & $0.32 \pm 0.017$ & $0.55 \pm 0.258$ & & & \\
\hline Experiment 2 & $408 \pm 67.4$ & $87 \pm 19.3$ & Type & 21 & 0.0002 \\
\hline
\end{tabular}

Experiment 1: a) Syrup removed every $2 \mathrm{~d}$ by groups started with $40 \mathrm{~g}$ bees and maintained at $15^{\circ} \mathrm{C}$ : b) rate of syrup removal per weight of live bees for each 2-d period. Experiment 2: syrup removed over a period of $5 \mathrm{~d}$ by $1.0-$ $\mathrm{kg}$ groups of bees maintained at $\approx 12^{\circ} \mathrm{C}$.

AFRICANIZED

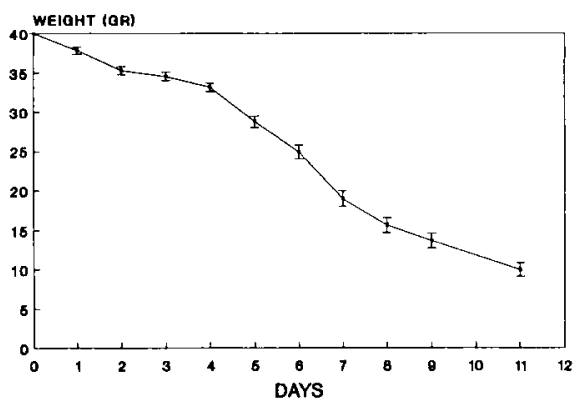

EUROPEAN

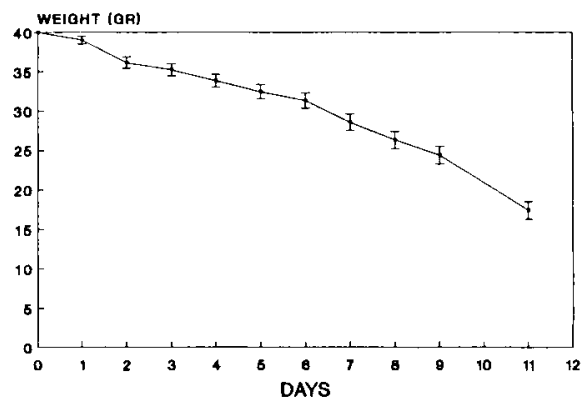

Fig 1. Estimated biomass of surviving workers (mean $\pm \mathrm{SE}$ ) maintained in hoarding cages at $15^{\circ} \mathrm{C}$ for $12 \mathrm{~d}$ (Experiment 1).

\section{Experiment 3}

Although only 2 colonies of each type were used to measure temperatures in broodless hives with comb, the same biomass of $A$ and $E$ workers produced similar temperature cross-sectional profiles at each temperature $\left(12,5\right.$ and $\left.-2,5^{\circ} \mathrm{C}\right)$. Also, the areas occupied by bees (as indicated by temperatures) were much smaller for both type of colonies at the lower temperature (fig 2). Measurements within each col- 
Table IV. Cluster dimensions as observed from side of cage (mean $\pm \mathrm{SE}$ of the area and of ratio of length to height of cross-sectional parabola at $20: 00 \mathrm{~h}$ ) on 1.0-kg groups of bees of 3 bee types at different ambient temperatures.

\begin{tabular}{|c|c|c|c|c|c|c|}
\hline \multirow[t]{2}{*}{ Variable/type } & \multicolumn{6}{|c|}{ Temperature } \\
\hline & \multicolumn{2}{|l|}{$20^{\circ} \mathrm{C}$} & $10^{\circ} \mathrm{C}$ & $5^{\circ} \mathrm{C}$ & \multicolumn{2}{|c|}{$0^{\circ} \mathrm{C}$} \\
\hline \multicolumn{7}{|l|}{ Area $\left(\mathrm{cm}^{2}\right)$} \\
\hline E & \multirow{3}{*}{$\begin{array}{l}332 \pm 19 \\
301 \pm 32 \\
250 \pm 29\end{array}$} & \multicolumn{2}{|c|}{$238 \pm 13$} & $209 \pm 12$ & \multicolumn{2}{|c|}{$201 \pm 8$} \\
\hline$E \times A$ & & \multicolumn{2}{|c|}{$202 \pm 16$} & $173 \pm 13$ & \multicolumn{2}{|c|}{$176 \pm 14$} \\
\hline$A$ & & \multicolumn{2}{|c|}{$263 \pm 18$} & $181 \pm 15$ & \multicolumn{2}{|c|}{$184 \pm 15$} \\
\hline \multicolumn{7}{|l|}{ Length: height } \\
\hline E & $1.56 \pm 0.13$ & & $63 \pm 0.16$ & $1.71 \pm 0.18$ & \multirow{3}{*}{\multicolumn{2}{|c|}{$\begin{array}{l}2.46 \pm 0.44 \\
2.68 \pm 0.48 \\
2.74+0.42\end{array}$}} \\
\hline$E \times A$ & $1.59 \pm 0.18$ & & $65 \pm 0.51$ & $2.74 \pm 0.74$ & & \\
\hline A & $2.20 \pm 0.53$ & & $20 \pm 0.26$ & $2.33 \pm 0.23$ & & \\
\hline \multirow[t]{2}{*}{ Source } & \multicolumn{3}{|c|}{ Area } & \multicolumn{3}{|c|}{ Length: height ratio } \\
\hline & $\mathrm{F}$ & $d f$ & $P>F$ & $\mathrm{~F}$ & $d f$ & $P>F$ \\
\hline Type & 1.47 & 2,12 & 0.2677 & 0.90 & 2,12 & 0.4327 \\
\hline Temperature & 41.72 & 3,36 & 0.0001 & 5.81 & 3,36 & 0.0024 \\
\hline Type-Temperature & 3.64 & 6,36 & 0.0063 & 1.48 & 6,36 & 0.2143 \\
\hline
\end{tabular}

Results of repeated measure ANOVA on the effects of bee type and temperature on the 2 variables are given (Experiment 2).

ony at each temperature were very consistent, and are therefore only presented once in figure 2.

\section{Experiment 4}

All $5 \mathrm{E}$ and $5 \mathrm{~A}$ colonies had died after 10 wk in the cold room. Total Africanized worker mortality was not different from that in European colonies (table VI). Also, differences between the types in total weight loss or rate of weight loss (rated to biomass) were not clearly detectable in these colonies (table VI). Since only the final amount of dead workers was measured, there could have been differences in the mortality curves of workers, and also differ- ences in the time of death of colonies that were not detectable with our observations.

\section{DISCUSSION}

This series of experiments indicate that some of the earlier hypotheses of potential winter mortality of Africanized colonies presented to explain their ecological distributions were not correct. There are no marked differences in aggregation and temperature regulation under cold conditions between European and Africanized groups of naturally encountered sizes. Also, instead of the hypothesized higher rates of sucrose store utilization in Africanized groups, under some conditions groups of Africanized bees 
Table V. Core temperatures (mean $\pm \mathrm{SE}$ in ${ }^{\circ} \mathrm{C}$ taken at 8:00 and 20:00 in 1.0-kg groups of 3 types of bees maintained at different temperatures.

\begin{tabular}{|c|c|c|c|c|c|c|}
\hline \multirow[t]{2}{*}{ Variable/type } & \multicolumn{6}{|c|}{ Temperature } \\
\hline & \multicolumn{2}{|l|}{$20^{\circ} \mathrm{C}$} & $10^{\circ} \mathrm{C}$ & $5^{\circ} \mathrm{C}$ & \multicolumn{2}{|c|}{$0^{\circ} \mathrm{C}$} \\
\hline \multicolumn{7}{|l|}{ Core temp at $8: 00 \mathrm{~h}$} \\
\hline E & $26.6 \pm 0.7$ & \multicolumn{2}{|c|}{$20.9 \pm 0.9$} & $18.4 \pm 1.4$ & \multicolumn{2}{|c|}{$7.2 \pm 2.2$} \\
\hline$E \times A$ & $28.5 \pm 0.9$ & \multicolumn{2}{|c|}{$24.1 \pm 0.6$} & $19.6 \pm 1.4$ & \multicolumn{2}{|c|}{$8.1 \pm 2.9$} \\
\hline A & $28.4 \pm 0.8$ & \multicolumn{2}{|c|}{$21.4 \pm 1.2$} & $18.3 \pm 1.8$ & \multicolumn{2}{|c|}{$9.7 \pm 1.9$} \\
\hline \multicolumn{7}{|c|}{ Core temp at $20: 00 \mathrm{~h}$} \\
\hline & $28.2 \pm 0.2$ & \multicolumn{2}{|c|}{$22.6 \pm 1.1$} & $19.8 \pm 1.4$ & \multicolumn{2}{|c|}{$19.0 \pm 1.9$} \\
\hline$E \times A$ & $28.0 \pm 0.5$ & \multicolumn{2}{|c|}{$25.3 \pm 0.8$} & $21.0 \pm 1.4$ & \multicolumn{2}{|c|}{$19.1 \pm 3.1$} \\
\hline A & $28.7 \pm 0.4$ & \multicolumn{2}{|c|}{$23.2 \pm 1.2$} & $21.0 \pm 1.0$ & \multicolumn{2}{|c|}{$20.7 \pm 1.5$} \\
\hline \multirow[t]{2}{*}{ Source } & \multicolumn{3}{|c|}{ Temp at $8: 00 \mathrm{~h}$} & \multicolumn{3}{|c|}{ Temp at $20: 00 \mathrm{~h}$} \\
\hline & $\mathrm{F}$ & $d f$ & $P>F$ & $\mathrm{~F}$ & $d f$ & $P>F$ \\
\hline Type & 1.20 & 2,12 & 0.3346 & 0.29 & 2,12 & 0.7563 \\
\hline Temperature & 91.27 & 3,36 & 0.0001 & 37.62 & 3,36 & 0.0001 \\
\hline Type-temperature & 0.43 & 6,36 & 0.8512 & 0.63 & 6,36 & 0.7053 \\
\hline
\end{tabular}

Results of repeated measure ANOVA are given for core temperatures at each of the 2 times (Experiment 2).

Table VI. Initial and final conditions of 5 European and 5 Africanized colonies maintained in a cold room for $73 \mathrm{~d}$ at $0^{\circ} \mathrm{C}$ (Experiment 4).

\begin{tabular}{|c|c|c|c|c|}
\hline \multirow[t]{2}{*}{ Condition } & \multicolumn{2}{|c|}{ Type } & \multirow[t]{2}{*}{$F$} & \multirow[t]{2}{*}{$P>F$} \\
\hline & $E$ & $A$ & & \\
\hline $\begin{array}{l}\text { Initial worker } \\
\text { population }(\mathrm{kg})\end{array}$ & $\begin{array}{l}2.75 \\
\pm 0.356\end{array}$ & $\begin{array}{l}2.67 \\
\pm 0.421\end{array}$ & 0.02 & 0.880 \\
\hline $\begin{array}{l}\text { Initial brood } \\
\text { area (sq in) }\end{array}$ & $\begin{array}{l}360.6 \\
\pm 48.95\end{array}$ & $\begin{array}{l}317.6 \\
\pm 36.41\end{array}$ & 0.49 & 0.503 \\
\hline $\begin{array}{l}\text { Recovered dead } \\
\text { workers }(\mathrm{kg})\end{array}$ & $\begin{array}{l}3.17 \\
\pm 0.429\end{array}$ & $\begin{array}{l}3.13 \\
\pm 0.391\end{array}$ & 0.01 & 0.938 \\
\hline $\begin{array}{l}\text { Final brood } \\
\text { area (sq in) }\end{array}$ & $\begin{array}{l}2.0 \\
\pm 1.09\end{array}$ & $\begin{array}{l}18.6 \\
\pm 10.42\end{array}$ & 2.51 & 0.152 \\
\hline $\begin{array}{l}\text { Ratio of wt loss/ } \\
\text { average worker pop }(\mathrm{kg} / \mathrm{kg})\end{array}$ & $\begin{array}{l}5.858 \\
\pm 0.8816\end{array}$ & $\begin{array}{l}4.897 \\
\pm 0.955\end{array}$ & 0.55 & 0.481 \\
\hline
\end{tabular}



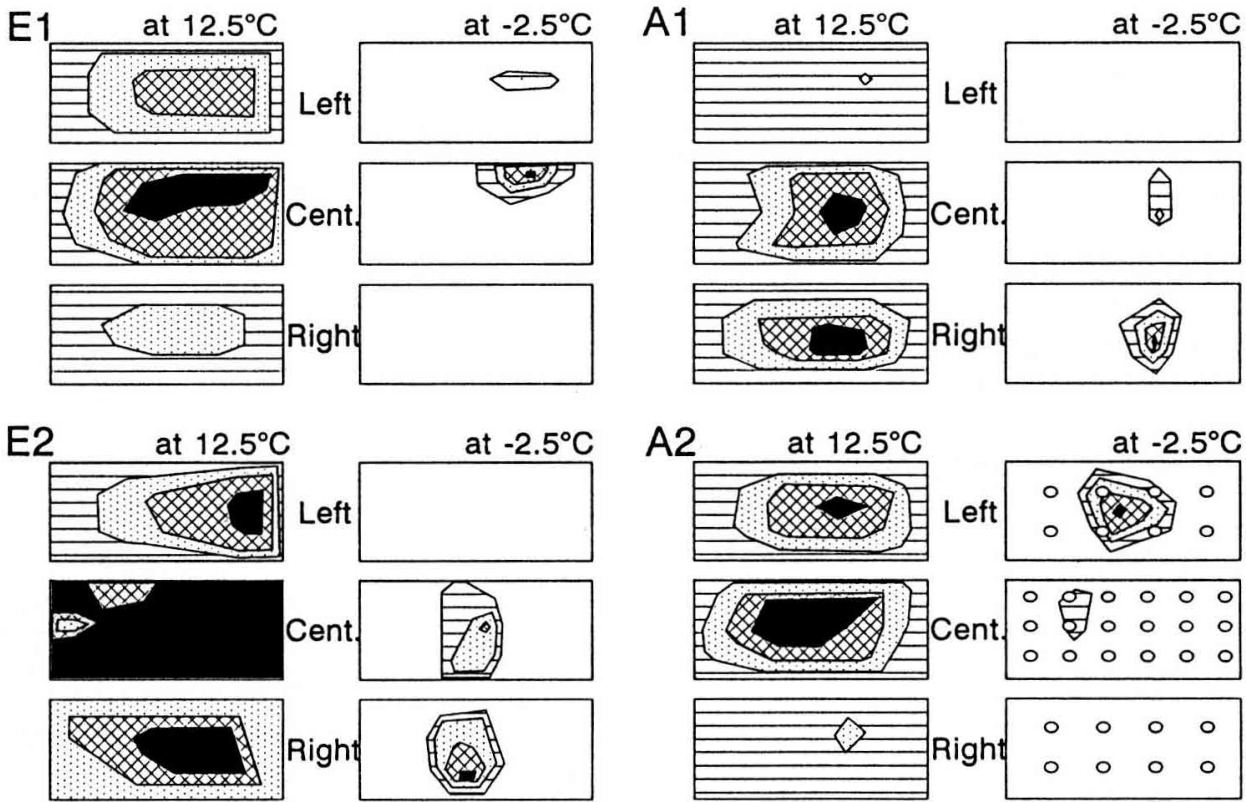

Fig 2. Temperature contours in 2 European colonies (E-1, E-2) and 2 Africanized colonies (A-1, A-2) estimated from measurements with copper-constantan thermocouples between frames 2-3 (left), 5-6 (center), and 8-9 (right) at each of 2 ambient temperatures $\left(12,5\right.$ and $-2.5^{\circ} \mathrm{C}$ ). Approximate positions of the thermocouples in each of the spaces between frames are indicated in colony A-2 at $-2.5^{\circ} \mathrm{C}$ (Experiment 3). Temperatures between frames: $\geq 30^{\circ} \mathrm{C} ; \mathrm{Q} 25-30^{\circ} \mathrm{C} ; \mathrm{W}^{2} 20-25^{\circ} \mathrm{C} ; \mathrm{15}-20^{\circ} \mathrm{C} ; \square$ $\leq 15^{\circ} \mathrm{C}$. o Thermocouple position between frames.

actually consume less stores. The possible causes of overwintering mortality in Africanized bees are probably more complex and involve interactions of life history traits such as honey collection, worker longevity and brood production.

\section{Aggregation and clustering}

A fairly widespread notion portrays Africanized colonies as having impaired thermoregulatory capacities. Recent studies (Villa et al, 1987; Dietz et al, 1988) have shown that Africanized and European colonies at high and low ambient temperatures have similar hive temperatures and that African- ized workers aggregate at low temperatures. In this study, small groups of Africanized workers actually clustered more tightly than European workers and maintained similar core temperatures. In larger $1.0-\mathrm{kg}$ groups differences in clustering were not as clear, although European bees had greater reduction in volume in response to decreasing temperatures. The fact that the shapes of temperature isolines appeared to be similar in the $1.5-\mathrm{kg}$ groups with comb suggests that major differences in aggregation may not occur in larger groups.

It is unclear whether observations of unnaturally small groups have any implications for the long-term survival of African- 
ized colonies. It could be that imperfect behavioral interactions among workers such as cluster separation from honey stores and decreased food exchange in larger colonies could compound overwintering problems.

\section{Food consumption}

The smaller worker size of Africanized workers has led to the hypothesis that colonies might have increased metabolic rates leading to earlier winter depletion of stores. This hypothesis was substantiated by the different slopes in the $\mathrm{VO}_{2}$ line for the 2 types of bees obtained by Southwick et al (1990). In contrast, our study shows that combless groups of Africanized workers, whether small or large, consumed significantly less sucrose syrup than European bees. Even though direct measurements of oxygen consumption can be more precise in detecting a short-term metabolic rate, measurements of store consumption can provide a much more realistic assessment of the energetic costs of thermoregulation over longer periods of time. Our measurements of sucrose removal fall within the broad ranges reported in the literature under similar situations (Free and Spencer-Booth, 1958; Heinrich, 1981). The absence of clearly higher food consumption by Africanized bees was also found in measurements of store consumption in colonies in this and other experiments. Experiments on weight loss of colonies at low temperatures in Argentina (Krell et al, 1985; Dietz et al, 1986, 1988, 1989), and in Colombia and Venezuela (Villa et al, 1987, 1993), have not indicated significant differences from European bees. Different rankings in the rate of store consumption in Africanized, hybrid and European bees (Villa et al, 1991, 1993) under different experimental conditions indicate that differences among European and Afri- canized bees in this character will be determined by local environmental conditions each winter, and will not necessarily be a significant factor determining higher overwintering mortality of Africanized colonies.

\section{Life history traits}

Other factors in which Africanized and European bees differed significantly in these tests will likely be more important in determining overwintering mortality. If the potentially tighter clustering of Africanized workers is compounded by shorter lifespans of workers which occurs during active months (Winston and Katz, 1981), and under periods of cold confinement $(40-\mathrm{g}$ groups in this study; Woyke, 1973; Villa et al, 1991, 1993) a significant proportion of highly African colonies could die in areas having longer winters. The increased mortality of highly African colony during winter will likely exert selective pressures to produce a hybrid population. The improved overwintering capabilities of this hybrid population as well as other more 'temperate' life history characteristics will likely produce a broad hybrid zone in the United States, similar to one found in Argentina (Sheppard et al, 1991).

\section{ACKNOWLEDGMENTS}

We thank L Beaman, R Colmenares, A Escalona and $T$ Stelzer for assistance in preparing the experiments and in data collection. G DeGrandiHoffman, J Grace, S Johnson, J Harbo, D Pashley, J Woodring and 3 anonymous reviewers provided useful comments on the manuscript. Facilities were provided by Miel Primavera, Venezuela. This study was carried out in cooperation with the Louisiana Agricultural Experiment Station.

Résumé - Thermorégulation, consommation des provisions et survie des 
abeilles européennes et africanisées (Apis mellifera $L$ ) en chambre froide. La possibilité pour les abeilles africanisées (A) de survivre dans des conditions hivernales ou de froid a été évaluée dans une chambre froide en comparant l'aggrégation, la température à l'intérieur des grappes, la consommation de saccharose ou de miel et la survie des ouvrières avec les mêmes données pour les abeilles européennes (E). Quatre types d'expériences ont été faites en chambre froide à Acarigua, Venezuela, en 1986 et $1987:$ 1) $40 \mathrm{~g}$ d'abeilles ouvrières dans des cagettes maintenues à $15^{\circ} \mathrm{C}$ pendant $10 \mathrm{j}$; 2) $1,0 \mathrm{~kg}$ d'ouvrières dans des cages grillagées maintenues durant $24 \mathrm{~h}$ à $20,10,5$ et $0^{\circ} \mathrm{C}$; 3) des colonies de $1,5 \mathrm{~kg}$ d'ouvrières, dépourvues de couvain et maintenues pendant $3 \mathrm{j}$ aux températures ambiantes de 12,5 et $-2,5^{\circ} \mathrm{C}$; 4) des colonies avec du couvain maintenues à $0^{\circ} \mathrm{C}$ durant 10 semaines.

Les petits groupes de $40 \mathrm{~g}$ d'abeilles $\mathrm{A}$ ont plus souvent formé une grappe à l'écart des nourrisseurs et en structure plus serrée que les ouvrières $E$ (Tableaux I et II); elles ont moins consommé de sirop de saccharose (tableau III) et la mortalité des ouvrières a été plus forte (fig 1). En revanche, les groupes d'abeilles de plus de $1 \mathrm{~kg}$ maintenues dans des cages grillagées (tableaux IV et V), et les colonies sans couvain à 12,5 et $-2,5^{\circ} \mathrm{C}$ (fig 2) n'ont pas présenté de différences. Les essaims d'abeilles $A$ de $1 \mathrm{~kg}$ sans rayons ont moins prévelé de sirop dans les nourrisseurs que les ouvrières $E$ (tableau III). Les 5 colonies $E$ et les 5 colonies $A$ étaient toutes mortes au bout de 10 semaines à $10^{\circ} \mathrm{C}$. Dans ces conditions, on n'a pas observé de différences dans la mortalité totale des ouvrières, ni dans la perte de poids (évaluée d'après la biomasse), ni dans la surface de couvain en fin d'expérience (tableau VI).

Ces expériences montrent que certaines interprétations antérieures concernant la mortalité hivernale des colonies africanisées n'étaient pas correctes (formation de la grappe et capacité thermorégulatrices fortement diminuées, taux métaboliques accrus) et que certains mécanismes comportementaux associés à la survie aux basses températures sont présents chez les abeilles africanisées et pourraient être améliorés par hybridation avec des abeilles européennes ou par sélection naturelle.

\section{Abeille africanisée / tolérance au froid / survie / thermorégulation}

Zusammenfassung - Thermoregula-
tion in einem kalten Raum, Futterver-
brauch und Überleben von afrikanisier-
ten und europäischen Honigbienen. Die Möglichkeit afrikanisierter Bienen (A), unter kalten oder winterlichen Bedingungen zu überleben, wurde durch den Vergleich von Traubenbildung, Temperatur innerhalb der Traube, Zucker- und Honigverbrauch und Überlebensrate der Arbeitsbienen in kalten Räumen mit Bienen europäischen Ursprungs (E) verglichen. In einem Kühlraum in Acarigua, Venezuela, wurden 1986 und 1987 vier Versuche durchgeführt: 1) $40 \mathrm{~g}$ Arbeiterinnen in Versuchskäfigen bei $15^{\circ} \mathrm{C}$ für $10 \mathrm{Tage}$; 2) 1.0 $\mathrm{kg}$ Bienen in Gitterkäfigen bei $20,10,5$, und $0^{\circ} \mathrm{C}$ für $24 \mathrm{~h}$; 3) brutlose Völker mit 1.5 $\mathrm{kg}$ Bienen bei einer Umgebungstemperatur von $12.5^{\circ}$ und $-2.5^{\circ} \mathrm{C}$ für drei Tage; 4) Völker mit Brut bei $0^{\circ} \mathrm{C}$ für 10 Wochen. Kleine Gruppen von $40 \mathrm{~g}$ A-Bienen bildeten häufiger Trauben abseits vom Futter und in engerem Zusammenschlu $\beta$ als $E$ Arbeiterinnen (Tabelle I und II), zeigten einen geringeren Verbrauch an Zuckersirup (Tabelle III) und eine höhere Arbeiterinnen-Mortalität (Abb 1). Unterschiede in der Traubenbildung und der Temperatur waren jedoch bei größeren Schwärmen von $1.0 \mathrm{~kg}$ in Gitterkäfigen (Tabelle IV und 
V) oder in brutlosen Völkern auf Waben bei $12.5^{\circ} \mathrm{C}$ und $-2.5^{\circ} \mathrm{C}$ nicht festzustellen (Abb 2). Schwärme von $1.0 \mathrm{~kg}$ ohne Waben mit Sirup-Futter-gefäßen nahmen weniger Sirup ab als E-Arbeiterinnen (Tabelle III). Alle $5 \mathrm{E}$ - und alle $5 \mathrm{~A}$-Völker waren nach 10 Wochen bei $0^{\circ} \mathrm{C}$ tot. Unter diesen Bedingungen war kein Unterschied in der Gesamtmortalität der Arbeiterinnen, im Gewichtsverlust (berechnet nach der Biomasse) oder der Brutmenge am Ende festzustellen (Tabelle VI). Diese Versuche weisen darauf hin, daß einige frühere $\mathrm{Er}$ klärungen zur Wintermortalität afrikanisierter Völker nicht korrekt sind (stark verringerte Fähigkeit zur Traubenbildung und Temperaturregulierung, erhöhte Stoffwechselwerte) und daß einige der Verhaltensmerkmale, die für das Überleben im kalten Klima nötig sind, auch bei afrikanisierten Bienen vorhanden sind und sowohl durch Hybridisierung mit europäischen Bienen wie durch natürliche Selektion verbessert werden könnten.

\section{Afrikanisierte Bienen / Kältetoleranz / Überleben / Thermoregulation}

\section{REFERENCES}

Danka RG, Hellmich RL, Rinderer TE, Collins AM (1987) Diet selection ecology of tropically and temperately adapted honey bees. Anim Behav 35, 1858-1863

Dietz A, Krell R, Pettis, J (1986) The potential limit of survival for Atricanized bees in the United States. In: Proc Africanized Honey Bee Symp. Am Farm Bureau Res Found, Park Ridge, IL

Dietz A, Krell R, Pettis J (1988) Survival of Africanized and European honey-bee colonies confined in a refrigeration chamber. In: Africanized Bees and Bee Mites (Needham GR et al, eds) John Wiley, NY, 237-242

Dietz A, Leitner JF, Vergara C, Mejia M (1989) Effect of prolonged confinement in a refrigeration chamber on the survival of Africanized and European honey bee colonies. In: Proc 4th Am Bee Res Conf. Am Bee J 129, 815

Free JB, Spencer-Booth $Y$ (1958) Observations on the temperature regulation and food consumption of honeybees (Apis mellifera). J Exp Biol 35, 930-937

Heinrich B (1981) The mechanisms and energetics of honeybee swarm temperature regulation. J Exp Biol 91, 25-55

Kerr WE, del Rio SL, Barrionuevo MD (1982) Distribucao da abelha africanizada em seus limites ao sul. Cienc Cult 34, 1493-1442

Krell R, Dietz, Eischen FA (1985) A preliminary study on winter survival of Africanized and European honey bees in Cordoba, Argentina. Apidologie 16, 109-118

Kristsky $G$ (1991) Lessons from history, the spread of the honey bee in North America. Am Bee J, 367-370

Kulinčevic JM, Rothenbuhler WC (1973) Laboratory and field measurements of hoarding behavior in the honeybee. J Apic Res 12, 179182

Nuñez JA (1979) Comparative study of thermoregulation between European and Africanized Apis mellifera in Brazil. J Apic Res 18, 116-121

SAS Institute (1990) SAS/STAT User's Guide. SAS Institute, Cary, NC

Sheppard WS, Rinderer TE, Mazzoli JA, Stelzer FA, Shimanuki H (1991) Gene flow between African- and European-derived honey bee populations in Argentina. Nature 349, 782-784

Sokal RR, Rohlf FJ (1981) Biometry. WH Freeman, San Francisco, CA

Southwick EE, Roubik DW, Williams JM (1990) Comparative energy balance in groups of Africanized and European honey bees: ecological implications. Comp Biochem Physio/ 97A, 1-7

Steel RGD, Torrie JH (1980) Principles and Procedures of Statistics. McGraw-Hill, NY

Taylor OR (1977) The past and possible future spread of Africanized honeybees in the Americas. Bee World 58, 19-30

Taylor OR (1985) African bees: potential impact in the United States. Bull Entomol Soc Am $31,14-24$

Taylor OR, Spivak M (1984) Climatic limits of tropical African honeybees in the Americas. Bee World 65, 38-47 
Villa JD, Gentry C, Taylor OR (1987) Preliminary observations on thermoregulation, clustering, and energy utilization in African and European honey bees. J Kansas Entomol Soc 60, 4-14

Villa JD, Koeniger N, Rinderer TE (1991) Overwintering of Africanized, European, and hybrid honey bees in Germany. Environ Entomol 20, 39-43

Villa JD, Rinderer TE, Collins AM (1993) 'Overwintering' of Africanized, European, and hybrid honey bees in the Andes of Venezuela. Environ Entomol 22, 183-189
Winston ML, Katz SJ (1981) Longevity of crossfostered honey bee workers (Apis mellifera) of European and Africanized races. Can $J$ Zool 59, 1571-1575

Winston ML, Taylor OR, Otis GR (1984) Some differences between temperate European and tropical African and South American honeybees. Bee World 64, 12-21

Woyke J (1973) Experiences with Apis mellifera adansonii in Brazil and Poland. Apiacta 8 , 115-116 